\title{
Effect of Levels of Potassium on Yield, Nutrient Uptake, Fertility Status and Economics of Cotton Grown in Vertisol
}

\author{
P.N. Magare*, S.D. Jadhao, B.K. Farkade and D.V. Mali
}

Department of Soil Science \& Agricultural Chemistry, Dr. Panjabrao Deshmukh Krishi Vidyapeeth, Akola-444 104 (M.S), India

*Corresponding author

Keywords

Cotton, Aparent recovery, Fiber quality, Nutrient uptake, Nutrient status, Yield, Economics

Article Info

Accepted:

10 March 2018

Available Online:

10 April 2018

\section{A B S T R A C T}

The experiment was conducted to study the effect of levels of potassium on yield, nutrient uptake, fertility status and economics of cotton grown in Vertisol at Akola during kharif season of 2009-10 to 2011-12. There were seven treatments comprising of potassium application through soil and foliar along with $\mathrm{RDF}\left(50 \mathrm{~kg} \mathrm{~N}+25 \mathrm{~kg} \mathrm{P}_{2} \mathrm{O}_{5} \mathrm{ha}^{-1}\right)$ laid out in Randomized Block Design with three replications. The pooled results of the present experiment revealed that, application of $37.5 \mathrm{~kg} \mathrm{~K}_{2} \mathrm{O} \mathrm{ha}^{-1}$ along with recommended dose of fertilizers (50:25:0 NPK kg ha $\left.{ }^{-1}\right)$ recorded significantly highest seed cotton yield (14.64 q $\mathrm{ha}^{-1}$ ) followed by recommended dose of fertilizer $+25 \mathrm{~kg} \mathrm{~K}_{2} \mathrm{O} \mathrm{ha}^{-1}\left(14.15 \mathrm{q} \mathrm{ha}^{-1}\right)$. Lowest seed cotton yield $\left(9.91 \mathrm{q} \mathrm{ha}^{-1}\right)$ was recorded in control treatment. The soil fertility status and uptake of major nutrient was significantly influenced with the application of RDF + $37.5 \mathrm{~kg} \mathrm{~K}_{2} \mathrm{O} \mathrm{ha}{ }^{-1}$. The higher B: C ratio, GMR and NMR was observed with the application of $\mathrm{RDF}+37.5 \mathrm{~kg} \mathrm{~K}_{2} \mathrm{O} \mathrm{ha}{ }^{-1}$. Apparent recovery percentage and fiber quality parameters i.e. span length, uniformity ratio, fineness micronaire and bundle strength tenacity were improved with the application of $\mathrm{RDF}+37.5 \mathrm{~kg} \mathrm{~K}_{2} \mathrm{O} \mathrm{ha}^{-1}$.

\section{Introduction}

Cotton (Gossypium hirsutum) the white gold, is one of the most important commercial and industrial crop. It plays a key role in economical and social affairs of the world. It is considered as "King" of fibers and being important cash crop of the country, benefits several million people who are engaged in its cultivation, trade, processing, manufacturing, etc. India ranks $1^{\text {st }}$ in world in area under cotton cultivation having 101.20 lakh ha sharing 27.94 per cent of world area under cotton (34.10 million ha) with production of
31.00 million bales. In India production of 305 lakh bales and productivity of $386 \mathrm{~kg}$ lint ha ${ }^{-1}$ per year (Anonymous, 2010).

In Maharashtra, area under cotton is about 35.04 lakh ha with an average productivity of $227 \mathrm{~kg} \mathrm{ha}^{-1}$ and production 66 lakh bales. While the Vidarbha region contributes large share in area under cotton 13.60 lakh ha as well as cotton production 24 lakh bales in the state (Anonymous, 2010). Many constraints have been highlighted the complexities of cotton farming in India. The important issues in cotton production are moisture stress during 
the growth period, nutrient management and insect pest incidence. Due to these constraints cotton yield have sharply declined for the last half a decade thus reducing the area in distinct way year after year. Among yield sustaining factors, balanced crop nutrition is of great significance. Nutrients are absorbed by the plants both through roots and foliage and the foliar application has an advantage as it overcomes the losses of fertilizers through leaching, volatilization, fixation, etc.

As cotton is a cash crop, it is well recognized fact that agricultural economy of Vidarbha is dependent on production of cotton but average production of cotton is very low. There is ample scope to boost the yield by nutrient management. The cotton production is influenced by various components of production technologies. Among them a significant role is played by fertilizer treatments. Adequate nutritional supply is essential. Three major elements are needed in balanced quantity. Adequate potassium is necessary for reducing the physiological diseases to facilitate normal development, maturity of bolls and to improve quality of fibre.

Nitrogenous and phosphorus fertilizers are more frequently used by the farmers from several years leading to an imbalanced nutrient supply ratio. As a result, potassium status in soil was depleted remarkably from high to medium status. Potassium is an essential nutrient in crop nutrition and play important role in production and improving the quality. The beneficial effect of potassium on cotton was reported by several workers (Brar et al., 1994; Maninder Kaur et al., 2007). Further, foliar nutrition, when used as a supplement to the recommended soil fertilizer application is highly beneficial, as the crop gets benefited from foliar applied nutrients when the roots are unable to meet the nutrient requirement of the crop at its critical growth stage (Ebelhar and Ware, 1998). Hence, the experiment was conducted to work out the effect of levels of potassium application through soil and foliar along with RDF on seed cotton yield, nutrient uptake, fibre quality and economics of cotton.

\section{Materials and Methods}

The field experiment was conducted at Research Farm, Department of Soil Science and Agricultural Chemistry, Dr. Panjabrao Deshmukh Krishi Vidyapeeth, Akola during kharif season of 2009-10 to 2011-12 (Three years). The soil of experimental site was dark brown in colour, clay in texture with smectitic mineralogy. According to soil taxonomy, the soil is classified as hyperthermic family of Typic Haplustert. The soil having medium in organic carbon $\left(6.0 \mathrm{~g} \mathrm{~kg}^{-1}\right)$, low in available nitrogen $\left(157.27 \mathrm{~kg} \mathrm{ha}{ }^{-1}\right)$, very low in available phosphorus $\left(12.23 \mathrm{~kg} \mathrm{ha}^{-1}\right)$ and high in available potassium $\left(313.60 \mathrm{~kg} \mathrm{ha}^{-1}\right)$. The composite surface soil sample $(0$ to $30 \mathrm{~cm}$ depth) was collected from experimental site prior to start of field experiment. After harvest of crop treatment wise samples $(0-20 \mathrm{~cm})$ were collected and dried in shade and ground in mortar and wooden pestle and then passed through $2 \mathrm{~mm}$ sieve, labeled properly and preserved in polythene bags for subsequent analysis. The sieved samples were further passed through $0.5 \mathrm{~mm}$ sieve for estimation of organic carbon. The fertilizer application was given as per the treatments. Doses of nitrogen, phosphorus and potassium were applied through urea, single super phosphate and murate of potash at the time of sowing. Two to three seeds (Cotton AKH-8828) were dibbled per hill @ a distance of 60 x $30 \mathrm{~cm}$. Thinning and gap filling operations were undertaken at 15 days after sowing to maintain uniform population. The experiment was laid out in Randomized Block Design with seven treatments viz., $T_{1}$ RDF (50:25:00), $T_{2} \mathrm{RDF}+$ $12.5 \mathrm{~kg} \mathrm{~K}_{2} \mathrm{O} \mathrm{ha}{ }^{-1,} \mathrm{~T}_{3} \mathrm{RDF}+25 \mathrm{~kg} \mathrm{~K}_{2} \mathrm{O} \mathrm{ha}{ }^{-1}$, 
$\mathrm{T}_{4} \mathrm{RDF}+37.5 \mathrm{~kg} \mathrm{~K} \mathrm{O} \mathrm{ha}^{-1}, \mathrm{~T}_{5} \mathrm{RDF}+2 \%$ $\mathrm{KNO}_{3}$ Foliar spray (one), $\mathrm{T}_{6} \mathrm{RDF}+2 \% \mathrm{KNO} 3$ foliar spray (two), and $\mathrm{T}_{7}$ Absolute control with three replication. The plant samples were collected from each plot at harvest for recording dry matter yield and it was expressed on oven dry weight basis. Soil $\mathrm{pH}$ was determined by $\mathrm{pH}$ meter using 1:2.5 soil water suspension, electrical conductivity by conductivity meter (Jackson, 1973), organic carbon (OC) by Walkley and Black method as described by Jackson (1973), available N by alkaline potassium permanganate method as described by Subbiah and Asija (1956), available $\mathrm{P}$ by Olsen's method (Watanabe and Olsen, 1965), available $\mathrm{K}$ by flame photometer using Ammonium acetate ( $\mathrm{pH} 7.0)$ as an extractant as described by Hanway and Heidel (1952). The plant samples were analyzed at harvest stage for their total $\mathrm{N}$ by Kjeldahl method as described by Piper (1966), total $\mathrm{P}$ by Vanadomolybdate yellow colour method using di-acid extract (Jackson, 1973) and total $\mathrm{K}$ by Flame photometer as described by Piper (1966). The ginning percentage was determined and the fiber quality parameter viz., 2.5 per cent span length, uniformity ratio, fineness micronaire, bundle strength tenacity were evaluated at Ginning Training Centre, Central Institute for Research on Cotton Technology, Regional Quality Evaluation Unit, Nagpur. Fertilizer use efficiency was calculated by using the formula given by (Mohanty and Singh, 2002).

\section{Results and Discussion}

\section{Seed cotton and stalk yield}

The pooled result pertaining to seed cotton and stalk yield during three years of experimentation are presented in Table 1. The data in respect of seed cotton yield as influenced by various treatments was found significant. The recommended dose of fertilizer with increased levels of potassium increased the seed cotton yield. The significantly highest seed cotton yield $(13.67 \mathrm{q}$ $\mathrm{ha}^{-1}$ ) was recorded with the application of RD $+37.5 \mathrm{~kg} \mathrm{~K} \mathrm{~K}_{2} \mathrm{O} \mathrm{ha}{ }^{-1}\left(\mathrm{~T}_{4}\right)$ followed by application of $\mathrm{RD}+25 . \mathrm{Kg} \mathrm{K}_{2} \mathrm{O}$ ha $^{-1}(12.85 \mathrm{q}$ $\left.\mathrm{ha}^{-1}\right)\left(\mathrm{T}_{3}\right)$ which was at par with each other during 2011-12. Similar trend was also observed during 2009-10 and 2010-11. In case of stalk yield highest stalk yield (34.61 q ha ${ }^{-1}$ ) was observed in the treatment $37.5 \mathrm{~kg} \mathrm{~K}_{2} \mathrm{O}$ $\mathrm{ha}^{-1}$ followed by application of $25 \mathrm{~kg} \mathrm{~K}_{2} \mathrm{O} \mathrm{ha}^{-1}$ (32.65 $\mathrm{q} \mathrm{ha}^{-1}$ ) which was at par with each other. Similar trend was also observed during 2009-10 and 2010-11. The pooled data revealed that significantly highest seed cotton yield $\left(14.64 \mathrm{q} \mathrm{ha}^{-1}\right)$ was recorded in the treatment of recommended dose of fertilizer + $\begin{array}{llllll}37.5 & \mathrm{~kg} & \mathrm{~K}_{2} \mathrm{O} & \mathrm{ha}^{-1} & \left(\mathrm{~T}_{4}\right) & \text { followed by }\end{array}$ recommended dose of fertilizer $+25 \mathrm{~kg} \mathrm{~K}_{2} \mathrm{O}$ $\mathrm{ha}^{-1}\left(14.15 \mathrm{q} \mathrm{ha}^{-1}\right)\left(\mathrm{T}_{3}\right)$.

Lowest seed cotton yield (9.91 $\left.\mathrm{q} \mathrm{ha}^{-1}\right)$ was recorded in control treatment. Application of recommended dose of fertilizer $+37.5 \mathrm{~kg} \mathrm{~K}_{2} \mathrm{O}$ $\mathrm{ha}^{-1}$ recorded significantly highest cotton stalk yield $\left(35.50 \mathrm{q} \mathrm{ha}^{-1}\right)\left(\mathrm{T}_{4}\right)$ followed by RD +25 $\mathrm{kg} \mathrm{K}_{2} \mathrm{O}$ ha $^{-1}\left(34.79 \mathrm{q} \mathrm{ha}^{-1}\right)\left(\mathrm{T}_{3}\right), \mathrm{RD}+$ two spray of $2 \% \mathrm{KNO}_{3}\left(\mathrm{~T}_{6}\right), \mathrm{RD}+12.5 \mathrm{~kg} \mathrm{~K}_{2} \mathrm{O}$ ha ${ }^{-1}\left(T_{2}\right)$.

The positive effect of potassium on yield might be due to pronounced role of potassium in transport of photosynthates, photosynthesis and cell elongation has been observed by Sharma and Singh (2007). Cassman et al., (1989) revealed that, yield increases with $\mathrm{K}$ application on Vermiculitic soils because of high K fixing capacity. Parvez et al., (2005) also observed significant increase in seed cotton yield with increasing levels of potassium in soil because potassium is readily mobile nutrient within the plant tissue, its utilization is concerned with the formation of carbohydrate and proteins, synthesis of nucleic acid, chlorophyll and translocation of solutes which might have helped in increasing seed 
cotton yield.

\section{Uptake of nutrients by cotton}

The three years pooled mean data pertaining to the uptake of nitrogen, phosphorus and potassium by cotton are presented in Table 2 .

\section{Nitrogen}

In the year 2011-12 application of RD along with $12.5 \mathrm{~kg} \mathrm{~K}_{2} \mathrm{O} \mathrm{ha}^{-1}\left(\mathrm{~T}_{2}\right)$ and $25 \mathrm{~kg} \mathrm{~K}_{2} \mathrm{O} \mathrm{ha}{ }^{-1}$ $\left(\mathrm{T}_{3}\right), 37.5 \mathrm{~kg} \mathrm{~K}_{2} \mathrm{O} \mathrm{ha}{ }^{-1}\left(\mathrm{~T}_{4}\right), 2 \% \mathrm{KNO}_{3}$ spray (one) $\left(\mathrm{T}_{5}\right)$ and $2 \% \mathrm{KNO}_{3}$ spray (two) $\left(\mathrm{T}_{6}\right)$ found at par. Pooled data pertaining to uptake of nitrogen by cotton influenced significantly.

Highest $\mathrm{N}$ uptake $\left(67.71 \mathrm{~kg} \mathrm{~N}^{-1}\right)$ with the application of $37.5 \mathrm{~kg} \mathrm{~K}_{2} \mathrm{O} \mathrm{ha}^{-1}\left(\mathrm{~T}_{4}\right)$ along with recommended dose of fertilizer which was at par with recommended dose of fertilizer $+25 \mathrm{~kg} \mathrm{~K}_{2} \mathrm{O} \mathrm{ha}^{-1}\left(\mathrm{~T}_{3}\right)(65.98 \mathrm{~kg} \mathrm{~N}$ $\left.h^{-1}\right)$.

The increased uptake of $\mathrm{N}$ due to the potassium application indicated the synergistic effect of potassium. The foliar application of $\mathrm{K}$ also significantly influenced the uptake of nitrogen by cotton. Thirumuragan et al., (1984) also noted increased uptake of nitrogen due to absorption of nutrients by cotton. Further the application of high levels of potassium increased the uptake of nitrogen at critical growth stage.

\section{Phosphorus}

The pooled mean of three years revealed that application of RD along with $37.5 \mathrm{~kg} \mathrm{~K}_{2} \mathrm{O}$ ha $^{-1}$ recorded significantly highest $\mathrm{P}$ uptake (18.71 $\mathrm{kg} \mathrm{P} \mathrm{ha}{ }^{-1}$ ) followed by $\mathrm{RD}+25 \mathrm{~kg} \mathrm{P} \mathrm{ha}{ }^{-1}$ ) however, it was found at par. Application of potassium significantly influenced the uptake of phosphorus. The probable reason for the increased $\mathrm{P}$ uptake with $\mathrm{RDF}+37.5 \mathrm{~kg} \mathrm{~K} 2 \mathrm{O}$ $\mathrm{ha}^{-1}$ may due to the application of $\mathrm{K}$ increases the root activity of the growing plants considerably which resulted in the greater absorption and utilization of $\mathrm{P}$ have ultimately increased the $\mathrm{P}$ uptake (Mayilsamy and Iruthayaraj, 1980).

\section{Potassium}

The pooled analysis revealed that application of $\mathrm{RD}+37.5 \quad \mathrm{~kg} \quad \mathrm{~K}_{2} \mathrm{O} \quad \mathrm{ha}^{-1}$ recorded significantly highest uptake of potassium i.e. $71.80 \mathrm{~kg} \mathrm{~K} \mathrm{ha}{ }^{-1}$ followed by RD+25 kg ha ${ }^{-1}$ $\left(70.21 \mathrm{~kg} \mathrm{~K} \mathrm{ha}^{-1}\right)$. The uptake of $\mathrm{K}$ in cotton plant was significantly greater in the $\mathrm{K}$ applied plots when compared with RDF without potash $\left(\mathrm{T}_{1}\right)$ and control plots $\left(\mathrm{T}_{7}\right)$.

The increased $\mathrm{K}$ uptake by cotton might be due to higher doses of potassium in soil (Blaise et al., 2009). The addition of $\mathrm{K}$ probably increased the quantity which is immediately available to the plant, resulting into higher content and uptake of $\mathrm{K}$ (Mayilsamy and Iruthayaraj, 1980).

\section{Nutrient use efficiency (Apparent recovery)}

The treatment $\mathrm{T}_{7}$ i.e. absolute control was considered as control on that basis nutrient use efficiency was calculated and presented in Table 3. The nutrient use efficiency of nitrogen was increased due to application of recommended dose of fertilizer (50:25:00 $\mathrm{N}: \mathrm{P}: \mathrm{K} \mathrm{kg} \mathrm{ha}^{-1}$ ) with $25 \mathrm{~kg} \mathrm{~K}_{2} \mathrm{O} \mathrm{ha}^{-1}$ and 37.5 $\mathrm{kg} \mathrm{K}_{2} \mathrm{O} \mathrm{ha}^{-1}$.

Similar trend in use of efficiency of phosphorous was observed. Adarsha et al., (2004) concluded that increased understanding of the rate of nitrogen and phosphorus in cotton fields improved efficiency. Blaise and Singh (2004) reported that when K applied with $\mathrm{N}$ and $\mathrm{P}$ the efficiency of $\mathrm{K}$ increased though a response to potassium was not seen in dry land cotton. It is better to adopt a balanced fertilizers schedule (NPK application), where in $\mathrm{K}$ is applied as a prophylactic measure. 
Table.1 Yield of cotton as influenced by various treatments

\begin{tabular}{|c|c|c|c|c|c|c|c|c|}
\hline \multirow[t]{3}{*}{ Treatments } & \multicolumn{8}{|c|}{ Yield $\left(q\right.$ ha $\left.^{-1}\right)$} \\
\hline & \multicolumn{3}{|c|}{ Seed cotton } & \multirow{2}{*}{$\begin{array}{l}\text { Pooled } \\
\text { mean }\end{array}$} & \multicolumn{3}{|c|}{ Cotton stalk } & \multirow{2}{*}{$\begin{array}{l}\text { Pooled } \\
\text { mean }\end{array}$} \\
\hline & 2009-10 & 2010-1 & 2011-12 & & 2009-1 & 2010-1 & 2011-12 & \\
\hline $\mathrm{T}_{1}-\mathrm{RDF}$ 50:25:00 N:P:K kg ha ${ }^{-1}$ & 12.14 & 11.93 & 10.53 & 11.53 & 32.11 & 28.28 & 26.81 & 29.06 \\
\hline $\mathrm{T}_{2}-\mathrm{RD}+12.5 \mathrm{~kg} \mathrm{~K}_{2} \mathrm{O} \mathrm{ha}^{-1}$ & 13.61 & 12.40 & 10.93 & 12.31 & 33.10 & 31.48 & 27.39 & 30.65 \\
\hline $\mathrm{T}_{3}-\mathrm{RD}+25 \mathrm{~kg} \mathrm{~K}_{2} \mathrm{O} \mathrm{ha}^{-1}$ & 15.42 & 14.19 & 12.85 & 14.15 & 35.96 & 35.78 & 32.65 & 34.79 \\
\hline $\mathrm{T}_{4}-\mathrm{RD}+37.5 \mathrm{~kg} \mathrm{~K}_{2} \mathrm{O} \mathrm{ha}^{-1}$ & 15.50 & 14.77 & 13.67 & 14.64 & 35.63 & 36.28 & 34.61 & 35.50 \\
\hline $\mathrm{T}_{5}-\mathrm{RD}+2 \% \mathrm{KNO}_{3}$ (One spray) & 15.19 & 12.10 & 10.74 & 12.67 & 34.47 & 30.48 & 29.34 & 31.43 \\
\hline $\mathrm{T}_{6}-\mathrm{RD}+2 \% \mathrm{KNO}_{3}$ (Two spray) & 15.28 & 12.60 & 11.39 & 13.09 & 34.88 & 32.13 & 28.56 & 31.85 \\
\hline $\mathrm{T}_{7}-$ Absolute control & 11.82 & 9.53 & 8.39 & 9.91 & 28.17 & 24.27 & 21.32 & 24.59 \\
\hline $\mathrm{SE}(\mathrm{m}) \pm$ & 0.42 & 0.52 & 0.92 & 0.49 & 0.99 & 1.23 & 1.85 & 1.06 \\
\hline $\mathrm{CD}$ at $5 \%$ & 1.25 & 1.54 & 2.74 & 1.47 & 2.96 & 3.66 & 5.49 & 3.15 \\
\hline C.V & 5.18 & 7.21 & 14.24 & 6.83 & 5.16 & 6.83 & 11.17 & 5.90 \\
\hline
\end{tabular}

Table.2 Uptake of nutrients by cotton as influenced by various treatments

(Pooled mean 2009 to 2011-12)

\begin{tabular}{|c|c|c|c|}
\hline \multirow[t]{2}{*}{ Treatments } & \multicolumn{3}{|c|}{ Nutrient Uptake $\left(\mathrm{kg} \mathrm{ha}^{-1}\right)$} \\
\hline & Nitrogen & Phosphorus & Potassium \\
\hline $\mathrm{T}_{1}-\mathrm{RDF}$ 50:25:00 N:P:K kg ha ${ }^{-1}$ & 55.86 & 14.55 & 58.96 \\
\hline $\mathrm{T}_{2}-\mathrm{RD}+12.5 \mathrm{~kg} \mathrm{~K}_{2} \mathrm{O} \mathrm{ha}^{-1}$ & 58.96 & 15.25 & 63.05 \\
\hline $\mathrm{T}_{3}-\mathrm{RD}+25 \mathrm{~kg} \mathrm{~K}_{2} \mathrm{O} \mathrm{ha}^{-1}$ & 65.98 & 18.38 & 70.21 \\
\hline $\mathrm{T}_{4}-\mathrm{RD}+37.5 \mathrm{~kg} \mathrm{~K}_{2} \mathrm{O} \mathrm{ha}^{-1}$ & 67.71 & 18.71 & 71.80 \\
\hline $\mathrm{T}_{5}-\mathrm{RD}+2 \% \mathrm{KNO}_{3}($ One spray $)$ & 60.83 & 16.45 & 64.93 \\
\hline $\mathrm{T}_{6}-\mathrm{RD}+2 \% \mathrm{KNO}_{3}$ (Two spray) & 61.70 & 16.74 & 66.67 \\
\hline $\mathrm{T}_{7}-$ Absolute control & 48.15 & 12.26 & 52.20 \\
\hline $\mathrm{SE}(\mathrm{m}) \pm$ & 1.54 & 0.32 & 1.23 \\
\hline $\mathrm{CD}$ at $5 \%$ & 4.60 & 0.95 & 3.66 \\
\hline
\end{tabular}

Table.3 Nutrient use efficiency as influenced by various treatments (2011-12)

\begin{tabular}{|c|c|c|c|c|c|c|}
\hline \multirow[t]{2}{*}{ Treatments } & \multicolumn{3}{|c|}{$\begin{array}{l}\text { Apparent Nutrient } \\
\text { Recovery }(\%)\end{array}$} & \multicolumn{3}{|c|}{$\begin{array}{l}\text { Agronomic Efficiency (AE) } \\
\text { (Kg grain/kg nutrient applied) }\end{array}$} \\
\hline & $\mathrm{N}$ & $\mathrm{P}$ & $\mathrm{K}$ & $\mathrm{N}$ & $\mathrm{P}$ & $\mathrm{K}$ \\
\hline $\mathrm{T}_{1}-\mathrm{RDF}$ 50:25:00 N:P:K kg ha ${ }^{-1}$ & 15.42 & 9.16 & -- & 3.24 & 6.48 & -- \\
\hline $\mathrm{T}_{2}-\mathrm{RD}+12.5 \mathrm{~kg} \mathrm{~K}_{2} \mathrm{O} \mathrm{ha}^{-1}$ & 21.62 & 11.96 & 86.80 & 4.80 & 9.60 & 19.2 \\
\hline $\mathrm{T}_{3}-\mathrm{RD}+25 \mathrm{~kg} \mathrm{~K}_{2} \mathrm{O} \mathrm{ha}^{-1}$ & 35.66 & 24.98 & 72.84 & 8.48 & 16.96 & 19.96 \\
\hline $\mathrm{T}_{4}-\mathrm{RD}+37.5 \mathrm{~kg} \mathrm{~K}_{2} \mathrm{O} \mathrm{ha}^{-1}$ & 39.12 & 25.80 & 52.06 & 9.46 & 18.92 & 12.61 \\
\hline $\mathrm{T}_{5}-\mathrm{RD}+2 \% \mathrm{KNO}_{3}$ (One spray) & 25.36 & 16.76 & 127.30 & 5.52 & 11.04 & 27.60 \\
\hline $\mathrm{T}_{6}-\mathrm{RD}+2 \% \mathrm{KNO}_{3}$ (Two spray) & 27.10 & 17.92 & 72.35 & 6.36 & 12.72 & 15.90 \\
\hline $\mathrm{T}_{7}-$ Absolute control & -- & -- & -- & -- & -- & -- \\
\hline
\end{tabular}


Table.4 Fiber quality parameters of cotton as influenced by various treatments (2011-12)

\begin{tabular}{|c|c|c|c|c|}
\hline Treatments & $\begin{array}{l}2.5 \% \text { Span } \\
\text { length }(\mathrm{mm})\end{array}$ & $\begin{array}{c}\text { Uniformity } \\
\text { ratio }(\%)\end{array}$ & $\begin{array}{c}\text { Fineness } \\
\text { micronaire } \\
\left(1^{-6} \mathrm{~g} \mathrm{inch}^{-1}\right)\end{array}$ & $\begin{array}{l}\text { Bundle strength } \\
\text { tenacity at } 3.2 \\
\text { mm guage } \\
\left(\mathrm{g} \mathrm{tex}^{-1}\right)\end{array}$ \\
\hline $\mathrm{T}_{1}-\mathrm{RDF}$ 50:25:00 N:P:K kg ha- ${ }^{-1}$ & 27.07 & 52.67 & 3.80 & 20.53 \\
\hline $\mathrm{T}_{2}-\mathrm{RD}+12.5 \mathrm{~kg} \mathrm{~K}_{2} \mathrm{O} \mathrm{ha}^{-1}$ & 26.60 & 50.33 & 3.93 & 20.20 \\
\hline $\mathrm{T}_{3}-\mathrm{RD}+25 \mathrm{~kg} \mathrm{~K}_{2} \mathrm{O} \mathrm{ha}^{-1}$ & 27.20 & 48.67 & 4.00 & 20.13 \\
\hline $\mathrm{T}_{4}-\mathrm{RD}+37.5 \mathrm{~kg} \mathrm{~K}_{2} \mathrm{O} \mathrm{ha}^{-1}$ & 27.63 & 50.67 & 4.10 & 20.57 \\
\hline $\mathrm{T}_{5}-\mathrm{RD}+2 \% \mathrm{KNO}_{3}($ One spray $)$ & 26.10 & 51.33 & 4.00 & 20.43 \\
\hline $\mathrm{T}_{6}-\mathrm{RD}+2 \% \mathrm{KNO}_{3}$ (Two spray) & 26.47 & 51.03 & 4.03 & 20.23 \\
\hline $\mathrm{T}_{7}-$ Absolute control & 25.54 & 51.00 & 4.07 & 19.20 \\
\hline $\mathrm{SE}(\mathrm{m}) \pm$ & 0.48 & 1.05 & 0.22 & 0.44 \\
\hline $\mathrm{CD}$ at $5 \%$ & NS & NS & NS & NS \\
\hline
\end{tabular}

Table.5 Chemical properties of soil after harvest of cotton as influenced by various treatments

\begin{tabular}{|c|c|c|c|}
\hline Treatments & pH (1: 2.5) & $\mathrm{EC}\left(\mathrm{dS} \mathrm{m} \mathrm{m}^{-1}\right)$ & Org. C. $\left(\mathrm{g} \mathrm{kg}^{-1}\right)$ \\
\hline $\mathrm{T}_{1}-\mathrm{RDF}$ 50:25:00 N:P:K kg ha ${ }^{-1}$ & 8.13 & 0.23 & 6.41 \\
\hline $\mathrm{T}_{2}-\mathrm{RD}+12.5 \mathrm{~kg} \mathrm{~K}_{2} \mathrm{O} \mathrm{ha}^{-1}$ & 8.14 & 0.29 & 6.30 \\
\hline $\mathrm{T}_{3}-\mathrm{RD}+25 \mathrm{~kg} \mathrm{~K}_{2} \mathrm{O} \mathrm{ha}{ }^{-1}$ & 8.16 & 0.31 & 6.43 \\
\hline $\mathrm{T}_{4}-\mathrm{RD}+37.5 \mathrm{~kg} \mathrm{~K}_{2} \mathrm{O} \mathrm{ha}^{-1}$ & 8.15 & 0.34 & 6.57 \\
\hline $\mathrm{T}_{5}-\mathrm{RD}+2 \% \mathrm{KNO}_{3}$ (One spray) & 8.16 & 0.26 & 6.21 \\
\hline $\mathrm{T}_{6}-\mathrm{RD}+2 \% \mathrm{KNO}_{3}$ (Two spray) & 8.17 & 0.25 & 6.20 \\
\hline $\mathrm{T}_{7}-$ Absolute control & 8.18 & 0.24 & 6.15 \\
\hline $\mathrm{SE}(\mathrm{m}) \pm$ & 0.08 & 0.03 & 0.08 \\
\hline $\mathrm{CD}$ at $5 \%$ & NS & NS & 0.24 \\
\hline Initial value & 8.20 & 0.12 & 6.0 \\
\hline
\end{tabular}

Table.6 Available nutrient status of soil after harvest of cotton as influenced by various treatments

\begin{tabular}{|c|c|c|c|}
\hline \multirow[t]{2}{*}{ Treatments } & \multicolumn{3}{|c|}{ Available nutrients $\left(\mathrm{kg} \mathrm{ha}^{-1}\right)$} \\
\hline & Nitrogen & Phosphorus & Potassium \\
\hline $\mathrm{T}_{1}-\mathrm{RDF}$ 50:25:00 N:P:K kg ha ${ }^{-1}$ & 164.1 & 15.20 & 318.1 \\
\hline $\mathrm{T}_{2}-\mathrm{RD}+12.5 \mathrm{~kg} \mathrm{~K}_{2} \mathrm{O} \mathrm{ha}^{-1}$ & 166.2 & 16.02 & 325.2 \\
\hline $\mathrm{T}_{3}-\mathrm{RD}+25 \mathrm{~kg} \mathrm{~K}_{2} \mathrm{O} \mathrm{ha}^{-1}$ & 175.8 & 16.69 & 329.6 \\
\hline $\mathrm{T}_{4}-\mathrm{RD}+37.5 \mathrm{~kg} \mathrm{~K}_{2} \mathrm{O} \mathrm{ha}^{-1}$ & 180.4 & 17.13 & 334.3 \\
\hline $\mathrm{T}_{5}-\mathrm{RD}+2 \% \mathrm{KNO}_{3}($ One spray $)$ & 165.2 & 15.67 & 320.1 \\
\hline $\mathrm{T}_{6}-\mathrm{RD}+2 \% \mathrm{KNO}_{3}$ (Two spray) & 168.9 & 15.94 & 321.5 \\
\hline $\mathrm{T}_{7}-$ Absolute control & 152.1 & 12.19 & 306.7 \\
\hline $\mathrm{SE}(\mathrm{m}) \pm$ & 2.39 & 0.44 & 0.73 \\
\hline $\mathrm{CD}$ at $5 \%$ & 7.10 & 1.32 & 2.18 \\
\hline Initial value & 157.27 & 12.23 & 313.6 \\
\hline
\end{tabular}


Table.7 Monetary returns of cotton as influenced by various treatments (pooled mean)

\begin{tabular}{|c|c|c|c|c|c|}
\hline Treatments & $\begin{array}{l}\text { Yield } \\
\left(\mathrm{q} \mathrm{ha}^{-1}\right)\end{array}$ & $\begin{array}{l}\text { COC } \\
\text { (Rs.) }\end{array}$ & $\begin{array}{l}\text { GMR } \\
\text { (Rs.) }\end{array}$ & $\begin{array}{l}\text { NMR } \\
\text { (Rs.) }\end{array}$ & $\begin{array}{l}\text { B:C } \\
\text { ratio }\end{array}$ \\
\hline $\mathrm{T}_{1}-\mathrm{RDF}$ 50:25:00 N:P:K kg ha-1 & 11.53 & 24057 & 48799 & 24742 & 2.02 \\
\hline $\mathrm{T}_{2}-\mathrm{RD}+12.5 \mathrm{~kg} \mathrm{~K}_{2} \mathrm{O} \mathrm{ha}^{-1}$ & 12.31 & 24377 & 51656 & 27279 & 2.11 \\
\hline $\mathrm{T}_{3}-\mathrm{RD}+25 \mathrm{~kg} \mathrm{~K}_{2} \mathrm{O} \mathrm{ha}^{-1}$ & 14.15 & 25108 & 59512 & 34404 & 2.37 \\
\hline $\mathrm{T}_{4}-\mathrm{RD}+37.5 \mathrm{~kg} \mathrm{~K}_{2} \mathrm{O} \mathrm{ha}^{-1}$ & 14.64 & 25374 & 61621 & 36247 & 2.42 \\
\hline $\mathrm{T}_{5}-\mathrm{RD}+2 \% \mathrm{KNO}_{3}$ (One spray) & 12.67 & 25762 & 53050 & 27288 & 2.05 \\
\hline $\mathrm{T}_{6}-\mathrm{RD}+2 \% \mathrm{KNO}_{3}$ (Two spray) & 13.09 & 27216 & 54662 & 27446 & 2.00 \\
\hline $\mathrm{T}_{7}-$ Absolute control & 9.91 & 22353 & 41412 & 19059 & 1.85 \\
\hline $\mathrm{SE}(\mathrm{m}) \pm$ & 0.49 & & 1661 & 1596 & \\
\hline $\mathrm{CD}$ at $5 \%$ & 1.47 & & 4936 & 4741 & \\
\hline
\end{tabular}

\section{Fiber quality}

The results on fiber quality parameters i.e. span length, uniformity ratio, fineness micronaire and bundle strength tenacity are predicted in Table 4. The results in respect of quality parameters were non significant however they were numerically higher with recommended dose of fertilizer alonwith increased levels of potassium. The findings corroborates with the results reported by Bharambe et al., (1997), Raskar et al., (2001), Anonymous (2004) and Mehta et al., (2009).

\section{Chemical properties}

The data in respect of $\mathrm{pH}$ and electrical conductivity and organic carbon in soil after harvest of cotton are presented in Table 5. $\mathrm{pH}$ and electrical conductivity of soil after harvest of cotton was found to be nonsignificant. The organic content of soil after harvest of cotton as influenced by various treatment \& recorded significantly highest $6.57 \mathrm{~g} \mathrm{~kg}^{-1}$ followed by $\mathrm{RD}+25 \mathrm{~kg} \mathrm{~K}_{2} \mathrm{O} \mathrm{ha}$ which were $6.43 \mathrm{~g} \mathrm{~kg}^{-1}$. The organic carbon content was recorded lowest under control treatment $\left(\mathrm{T}_{7}\right)$. The status of organic carbon under all the treatments was improved as against initial status $\left(6.00 \mathrm{~g} \mathrm{~kg}^{-1}\right)$ which may be due to root biomass as a result of vigorous growth and yield of seed cotton. It may be also observed that the organic carbon content was increased with the period of experimentation i.e. from 2009-10 to 201112. The slight increase in organic carbon content in soil over initial values $\left(6.0 \mathrm{~g} \mathrm{~kg}^{-1}\right)$ may be due to the balanced nutrition of the crop might be resulted in increase in soil biomass. Similar results were also reported by Krishnan and Loweduraj (1997).

\section{Fertility status}

The data depicted in Table 6 indicates the available nitrogen, phosphorus and potassium status of soil after harvest of cotton during 2011-12.

\section{Available nitrogen}

It revealed that, the availability of nitrogen was increased with the year of experimentation. The initial available $\mathrm{N}$ was $157.27 \mathrm{~kg} \mathrm{ha}^{-1}$ which was increased under all the treatments except control $\left(\mathrm{T}_{7}\right)$. The application of $\mathrm{RD}+37.5 \mathrm{~kg} \mathrm{~K}_{2} \mathrm{O} \mathrm{ha}^{-1}\left(\mathrm{~T}_{4}\right)$ recorded significantly highest available nitrogen (180.4 $\mathrm{kg} \mathrm{N} \mathrm{ha}^{-1}$ ) followed by RDF + $25 \mathrm{~kg} \mathrm{~K}_{2} \mathrm{O}$ ha $^{-1}\left(175.8 \mathrm{~kg} \mathrm{~N}^{-1}\left(\mathrm{~T}_{3}\right)\right.$. The decrease in available $\mathrm{N}$ in control treatment may be due to continuous cropping devoid of nitrogen. The increased available $\mathrm{N}$ content might be due to synergistic effect of potassium application resulted in increasing nitrogen availability in soil. Ghosh et al., 
(2001) also reported the favorable effect of potassium application on available nitrogen status of the soil.

\section{Available phosphorus}

The available phosphorus was significantly influenced with the application $\mathrm{RD}+37.5 \mathrm{~kg}$ $\mathrm{K}_{2} \mathrm{O}$ ha $^{-1}$ (17.13 kg P ha ${ }^{-1}$ ) followed by RDF + $25 \mathrm{~kg} \mathrm{~K}_{2} \mathrm{O}$ ha $^{-1}\left(16.69 \mathrm{~kg} \mathrm{P} \mathrm{ha}^{-1}\right)$. The lowest phosphorus was recorded under control.

Available phosphorus content was increased due to the application of potassium might be due to the balanced nutrients concentration in soil solution resulted in better phosphorus use efficiency. These results are supported by Jamadagni and Birari (1994).

\section{Available potassium}

Application of RD $+37.5 \mathrm{~kg} \mathrm{ha}^{-1} \mathrm{~K}_{2} \mathrm{O}$ recorded significantly highest $\mathrm{K} 334.3 \mathrm{~kg} \mathrm{~K}_{2} \mathrm{O}$ ha $^{-1}\left(\mathrm{~T}_{4}\right)$ it was found at par with treatment receiving $\mathrm{RDF}$ $+25 \mathrm{~kg} \mathrm{~K}_{2} \mathrm{O} \mathrm{ha}{ }^{-1}\left(\mathrm{~T}_{3}\right)$. The initial status of available $\mathrm{K}$ was $313.6 \mathrm{~kg} \mathrm{ha}{ }^{-1}$, which was improved under all the treatments with the continuous application of $\mathrm{RDF}$ and $\mathrm{RD}$ along with different levels of $\mathrm{K}_{2} \mathrm{O}$ and $\mathrm{KNO}_{3}$ except control. The increasing availability of potassium in soil might be due to application of potassium. Joshi (1993) observed the increased available status of NPK due to application of $100 \%$ RDF.

\section{Economics}

The benefit cost ratio of cotton was influenced by various treatments and presented in Table 7 . The B: C ratio was found significantly higher in the treatment of recommended dose of fertilizer with $37.5 \mathrm{~kg} \mathrm{~K}_{2} \mathrm{O} \mathrm{ha}^{-1}$ (2.42) followed by RD with $25 \mathrm{~kg} \mathrm{~K}_{2} \mathrm{O} \mathrm{ha}^{-1}$ (2.37), however these treatments were found at par. The lowest B: C ratio was recorded in control treatment.

From the three years of study, it could be concluded that, application of $37.5 \mathrm{~kg} \mathrm{~K}_{2} \mathrm{O} \mathrm{ha}^{-1}$ along with recommended dose of fertilizer (50:25:0 NPK $\mathrm{kg} \mathrm{ha}^{-1}$ ) recorded significantly higher seed cotton yield (14.64 $\left.\mathrm{q} \mathrm{ha}^{-1}\right)$ and $\mathrm{B}: \mathrm{C}$ ratio (2.42) respectively. The uptake of nutrients (NPK) and fiber quality was significantly improved due to potassium application.

The application of potassium along with $\mathrm{N} \& \mathrm{P}$ also helped to improve chemical properties and soil fertility status beside improvement of span length, uniformity ratio, fineness micronaire and bundle strength tenacity were improved with the application of $\mathrm{RD}+37.5 \mathrm{~kg} \mathrm{~K}_{2} \mathrm{O} \mathrm{ha}{ }^{-1}$.

\section{References}

Adarsha, T. S., Patil, B. C., Vanaja, M. and Srinivas, K. 2004. Nitrogen and Phosphorus management of cotton under different moisture regimes. International Symposium on "Strategies for sustainable cotton production - A global Vision" $23^{\text {rd }}$ to $25^{\text {th }}$ November, 2004. UAS, Dharwad. $365-365$.

Anonymous, 2004. Effect of drip fertigation on cotton. Department of Soil Science and Agricultural Chemistry, Annual Report, Dr. PDKV, Akola.

Anonymous, 2010. http:www.cottoncrop. com.

Bharambe, P. R., Narwade, S. K., Oza, S. R., Vaishnava, V. G., Shelke, D. K. and Jadhav, G. S. 1997. Nitrogen management in cotton through drip irrigation. J. Indian Soc. Soil Sci. 45 (4): 705-709.

Blaise, D., Singh, J. V. and Bonde, A. N. 2009. Agro organic management for sustainable cotton production in Central India "Souvenir" National Symposium on "Changing World Order - Cotton Research, Development and Policy in context" August 10-12, 2004.

Brar, M. S., Brar, A. S., Takkar, P. N. and Singh, T. H. 1994. Effect of potassium supply on its concentration in plant and on yield parameters of American Cotton (Gossypium hirsutum L.) J. Potassium Res. 3 (4): 149-154.

Cassman, K, G., Roberts, B. A., Kerby, T. A., Bryant, D. C. and Higashi, S. L. 1989. Soil potassium balance and cumulative 
cotton response to annual potassium addition on a Vermicultic soil. Soil Sci. Soc. Am. J. 53: 805-812.

Ebelhar, M. W. and Ware, J. O. 1998. Summary of cotton yield response to foliar application of potassium nitrate and urea. Proc. Beltwide Cotton Conf. Memphis. Tenn. 1: 683-687.

Ghosh, A., Mandal, S. S. and Sarkar, S. 2001. Response of cotton to potassium, nitrogen and biofertilizers. J. Potassium Res. 17: 85-88.

Hanway, J. J. and Heidel, H. 1952. Soil analysis method as used in IOWA State College Soil Testing Laboratory. IOWA State College of Agriculture Bulletin, 57:1-13.

Jackson, M. L. 1973. Soil chemical analysis. (Edn-2) Prentice Hall of India, Private Limited, New Delhi, India: 69 -182.

Jamadagni, B. M. and Birari, S.P. 1994. Yield response of cowpea to varying levels of potassium and phosphorus on lateritic soil of Kokan region. J. Potassium Res. 10 (2): 192-195.

Joshi, M. 1993. Effect of split application of potassium on growth, yield of rainfed cotton. J. Indian Soc. Soil Sci. 52: 131133.

Krishnan, P. K. and Lourduraj, A. 1997. Different levels, time and method of application of nitrogen and potash on the uptake of nutrients and soil nutrient status in cotton. Madras Agric. J. 84 (6): 330334.

Maninder Kaur, Mandeep Kaur and Brar, A. S. 2007. Effect of potassium on the growth and yield of American Cotton (Gossypium hirsutum L.). J. Cotton Res. Dev. 21 (2): 187-190.

Mayilsamy, R. and Iruthayaraj, M. R. 1980. Effect of plant density and $\mathrm{N}$ application on the uptake of major nutrients by cotton. Madras Agric. J. 56 (1): 324-328.

Mehta, A. K., Thakral, S. K. and Saharan, H. S. 2009. Effect of organic and inorganic sources of nutrition on yield and fibre quality of cotton. J. Cotton Res. Dev. 23 (2): 253-257.

Mohanty, S.K., Singh, T. A. 2002. Fundamental of Soil Science. Indian Soc. of Soil Sci. IARI, New Delhi.

Parvez, H., Ashraf, M. and Makhdum, M. I. 2005. Influence of potassium rates and sources on seed cotton yield and yield components of some elite cotton cultivars. J. Plant Nutri. 27: 1295-1317.

Piper, C.S. 1966. Soil and plant analysis IV $^{\text {th }}$ edition University of Acelcide Adeitala, Australia. 135-200.

Raskar, B. S., Bhoi, P. G. and Pawar, D. D. 2001. Effect of planting technique and water soluble fertilizers on pre-monsoon cotton under drip irrigation J. Indian Soc. Cotton Improv. 26 (3): 138-143.

Sharma, S. K. and Singh, S. 2007. Yield, yield attributes and quality of cotton as influenced by foliar application of potassium. J. Cotton Res. Dev. 21(1): 5154.

Subbiah, B. V. and Asija, G. L.1956. A rapid procedure for determination of available nitrogen in soil. Current Sci. 25: 256-260.

Thirumurugan, V., Kolandaisamy, S. and Muthukrishnan, P. 1984. Studies on the response of hybrid cotton CBS-156 to varied spacing and graded levels of potassium. Madras Agric. J. 71: 195-197.

Watanabe, F. S. and Olsen's, S. R. 1965. Test of an ascorbic method for determining phosphorus in water and $\mathrm{NaHCO}_{3}$ extract from soil. Soil science Am. Proc. 29: 677678.

\section{How to cite this article:}

Magare, P.N., S.D. Jadhao, B.K. Farkade and Mali, D.V. 2018. Effect of Levels of Potassium on Yield, Nutrient Uptake, Fertility Status and Economics of Cotton Grown in Vertisol. Int.J.Curr.Microbiol.App.Sci. 7(04): 1292-1300. doi: https://doi.org/10.20546/ijcmas.2018.704.144 